\title{
我国深海矿产资源开发装备研发现状与展望
}

\author{
杨建民，刘否，吕海宁，林忠钦 \\ (上海交通大学, 上海 200240)
}

\begin{abstract}
摘要：浩瀚的大洋底部蕴藏着丰富的矿产资源，其种类多、储量大、品位高，具有巨大的开发利用前景，世界各国都在加快 深海矿产资源开发装备的研制。本文系统分析了国内外深海矿产资源开发技术装备的发展现状，从基础科学问题研究、关键 技术研发、海上试验验证等角度剖析我国技术装备存在的不足，总结归纳亟待解决的关键科学技术问题，并据此提出深海采 矿重载作业装备、矿石输送装备、水面支持装备的发展方向。研究提出深海矿产资源开发秉持重装、协同、智能、绿色的发 展理念, 加速推进核心技术创新和装备自主研发; 建议开展深海多金属结核开采示范工程建设, 加快推动深海矿产资源开发 关键技术装备研发，实现规模化海上试采，并着眼长期生产作业开展系统设计，促进商业化开采进程。
\end{abstract}

关键词：海底矿产；深海采矿；深海重载作业装备；矿石输送装备；水面支持装备

中图分类号: P744 文献标识码: A

\section{Deep-Sea Mining Equipment in China: Current Status and Prospect}

\author{
Yang Jianmin, Liu Lei, Lyu Haining, Lin Zhongqin
}

(Shanghai Jiao Tong University, Shanghai 200240, China)

\begin{abstract}
There are abundant mineral resources at the seafloor. These resources have rich varieties, vast reserves, high grade, and great development and utilization prospects. Countries in the world are accelerating the development of deep-sea mining equipment nowadays. This study analyzes the development status of the deep-sea mining equipment in China and abroad and investigates the deficiencies in technologies and equipment in China from the perspectives of fundamental scientific research, key technology development, and sea trial verification. Moreover, it summarizes the key scientific and technological issues to be resolved, and proposes the developing trends of deep-sea heavy operation equipment, ore transport equipment, and sea surface support vessels. We propose that deep-sea mining should adhere to the concepts of heavy equipment, collaboration, intelligence, and green development, and key technology innovation and independent research and development of the mining equipment should be promoted. Demonstration projects should be constructed for deep-sea polymetallic nodule mining to accelerate the development of deep-sea mining technologies and equipment, so as to realize large-scale sea trials, conduct system design for long-term operation, and promote commercial seabed mining.
\end{abstract}

Keywords: seabed mineral; deep-sea mining; deep-sea heavy operation equipment; ore transport equipment; sea surface support vessel

收稿日期 : 2020-10-20; 修回日期 : 2020-11-05

通讯作者: 杨建民, 上海交通大学船舶海洋与建筑工程学院教授, 研究方向为海洋深水平台、深海矿产资源开发; E-mail: jmyang@sjtu.edu.cn 资助项目：中国工程院咨询项目 “海洋装备发展战略研究” (2020-ZD-02)

本刊网址：www.engineering.org.cn/ch/journal/sscae 


\section{一、前言}

浩瀚的大洋底部蕴藏着丰富的矿产资源。已探 明具有开发前景的深海矿产资源包括多金属结核、 富钴结壳、多金属硫化物等, 其中锰、镍、钴等金 属的储量远高于陆地储量。如果能够安全、高效地 商业开采, 并且控制好作业过程中对海洋生态环境 的影响, 丰富的海洋矿产将成为陆上矿产资源的替 代资源, 满足未来一段时期内人类社会的经济发展 需求 [1]。因此, 世界各国都在加紧对海洋矿产资 源的探索与开采。

深海矿产资源开发研究始于 20 世纪 50 年代末, 美国、欧洲、日本等国家和地区主要针对深海多金 属结核, 研究各自的勘探与商业开采方案 [2,3], 同 时兼顾富钴结壳、多金属硫化物的开采技术研究; 20 世纪八九十年代, 韩国、印度、中国也相继加 入深海矿产资源开发队伍, 探索系统方案和商业 化开采方案 [4]; 近年来, 世界各国纷纷开展单体 和综合海试, 深海矿产资源开发技术装备取得显 著进展。

尽管海底矿产储量巨大、品位高, 然而开采难 度极大: 海底地形复杂、压力极高、无光照, 同时 存在海浪、洋流、内波等复杂海洋环境条件, 对作 业设备提出了极高的安全性要求; 开采过程中的多 系统协同控制和联合作业难度较高 [5]。此外, 需 要深入评估海底矿产资源开发对环境的影响, 提出 环境保护方案。因此, 目前深海矿产资源在世界范 围内尚未形成商业化开采。

面对我国经济快速发展过程中的矿产资源需求 以及建设海洋强国的战略需求, 勘探和开发深海矿 产资源迫在眉睫。我国在 20 世纪 80 年代末启动了 深海矿产资源开发技术装备研究, 聚焦管道提升式 深海矿产资源开发系统, 开展技术攻关和装备研发, 初步形成深海多金属结核开采系统的设计和装备研 发能力, 同时兼顾富钴结壳、多金属硫化物开采技 术装备的研发 [6]。

尽管我国已经完成一系列海上试验, 但系统设 计和研发能力、协同作业技术、关键技术装备研制 等与发达国家仍存在一定差距。一方面, 我国尚未 开展系统联合海试, 关键技术尚未获得有效验证, 核心装备研制能力、相关系统稳定性和可靠性亟待
提高, 实现矿区规模化开采仍存在较大困难; 另一 方面, 我国水下关键元器件、水下传感器、专用材 料研究存在短板, 大部分产品依赖进口。

综合来看, 深海矿产资源开发技术是目前深海 开发领域的重要研究课题。美国、欧洲、日本等发 达国家和地区已经掌握深海矿产资源开发的关键技 术和核心装备的制造能力, 一旦解决海底环保问题, 将可择机开展商业化开采 [6]。我国还处于深海矿 产资源开发技术的起步阶段, 亟需开展示范工程建 设, 大力发展关键技术装备, 加快规模化试采和商 业开采进程, 以期在国际海底矿产资源开发中获得 有利地位。

\section{二、国外深海矿产资源开发装备发展概述}

世界范围内针对深海矿产资源开发方案主要 分为拖斗式、连续斗绳式、自动穿梭艇式、管道提 升式。由于前 3 种采矿方式开采效率低、对环境破 坏严重, 已经逐渐淡出研究视线。目前, 深海矿产 资源开采研究集中在管道提升式深海采矿系统 [7], 包括海底矿石开采装备、矿石输送装备、水面支持 装备。

20 世纪 70 年代, 海洋管理公司等多个国际 财团在太平洋约 $5000 \mathrm{~m}$ 海底成功采集多金属结 核 [6]。随后, 德国、俄罗斯、日本、韩国、印度等 相继开展海试, 验证其技术装备 [1]。2017 年, 日 本完成 $1600 \mathrm{~m}$ 水深多金属硫化物的采集和提升海 试 [8], 标志着多金属硫化物开发技术又向前迈进一 步。近年来, 欧盟针对深海矿产资源开发分别设立 BlueMining、BlueNodules、iVAMOS! 等多个项目 [5]; 2017 年以来, 荷兰、比利时等国家多次成功进行深 海采矿装备海试与环境评估, 相应深海矿产资源开 发技术装备逐渐完善。表 1 总结了国外深海矿产资 源开发装备的发展现状。国外通过大量的海上试验, 建立了较为完善的深海矿产资源开发技术方案, 掌 握了关键技术研发和核心装备研制能力, 包括: 海 底矿石开采装备安全行走和高效采集、长距离泵管 输送流动保障、水下动力输送、全系统协同控制、 水下综合导航定位、重载装备海上布放回收等技术。

由于不可避免地对海底环境造成影响, 未来 深海矿产资源开发将着重解决作业过程中的环境问 
表 1 国外深海矿产资源开发装备发展现状

\begin{tabular}{|c|c|c|c|}
\hline 时间 / 年 & 国家/单位名称 & 水深 $/ \mathrm{m}$ & 试验内容 \\
\hline 1978 & 海洋管理公司（OMI） & 5500 & 多金属结核海试 \\
\hline 1978 & 海洋矿业协会（OMA） & 4570 & 多金属结核海试 \\
\hline 1979 & 海洋矿物公司（OMCO） & 5000 & 多金属结核海试 \\
\hline 1979 & 德国 / 普罗伊萨格公司（Preussag） & 2200 & 多金属软泥试采 \\
\hline 1990 & 俄罗斯 / 莫斯科地质勘探学院（МГРИ） & 79 & 水力提升系统海试 \\
\hline 1996 & $\begin{array}{c}\text { 印度 /海洋技术研究院（NIOT）、德国 } \\
\text { / 锡根大学 (University of Siegen) }\end{array}$ & 500 & 采矿车行走和采集试验 \\
\hline 1997 & 日本 / 多金属结核采矿系统研发项目 & 2200 & 钢丝绳和采矿机联合拖航试验 \\
\hline 2002 & $\begin{array}{c}\text { 日本 / 石油天然气金属矿物资源机构 } \\
\text { (JOGMEC) }\end{array}$ & 1600 & 采矿车行走试验 \\
\hline 2006 & 印度 /海洋技术研究院（NIOT） & 450 & 采矿车海试 \\
\hline 2009 & 韩国 / 地质资源研究院（KIGAM） & 100 & 输送系统海试 \\
\hline 2012 & $\begin{array}{c}\text { 日本 / 石油天然气金属矿物资源机构 } \\
\text { (JOGMEC) }\end{array}$ & 1600 & 采矿车采样试验 \\
\hline 2013 & 韩国 / 海洋科学技术院（KIOST） & 1370 & 采矿车海试 \\
\hline 2015 & $\begin{array}{c}\text { 韩国 /海洋科学技术院 (KIOST)、韩 } \\
\text { 国 / 海洋工程研究所 (KRISO) }\end{array}$ & 1200 & 水力提升系统海试 \\
\hline 2017 & $\begin{array}{c}\text { 日本 / 石油天然气金属矿物资源机构 } \\
\text { (JOGMEC) }\end{array}$ & 1600 & 采矿车采集和水力提升试验 \\
\hline 2017 & 比利时 / 德米集团（DEME） & 4571 & 采矿车行走海试, 环境评估 \\
\hline 2017 & $\begin{array}{c}\text { 加拿大 / 鹦鹉螺矿业公司（Nautilus } \\
\text { Minerals） }\end{array}$ & - & 采矿车带水试验 \\
\hline 2017 & $\begin{array}{c}\text { 欧盟 / 可行性替代采矿作业系统项目 } \\
\text { (;VAMOS!) }\end{array}$ & - & 采矿车定位导航及感知试验 \\
\hline 2018 & 荷兰 / 皇家 IHC 公司（Royal IHC） & 300 & 采矿车行走试验 \\
\hline 2019 & 荷兰 / 皇家 IHC 公司（Royal IHC） & 300 & 采矿车行走试验 \\
\hline
\end{tabular}

题, 研发环境友好型开采装备, 通过低扰动行走和 高效精准采集来降低对环境影响。在现代信息技术、 大数据、人工智能等技术的支持下，深海矿产资源 开发系统将进一步提高精准作业、协同控制、长期 运维、实时调控的能力, 高精度和智能化的开采装 备成为未来发展趋势。

\section{三、我国深海矿产资源开发装备发展现状}

我国深海矿产资源开发选择了管道提升式开采 方案, 主要针对深海多金属结核开展研究, 同时兼 顾富钴结壳、多金属硫化物; 主要开发装备包括深 海采矿重载作业装备、矿石输送装备、水面支持装 备。表 2 归纳了目前我国深海矿产资源开发装备取 得的主要进展。本节重在阐述相关技术装备的发展 现状，而不涉及开发过程中的环境问题。

\section{（一）深海采矿重载作业装备}

深海矿产资源开发的深海采矿重载作业装备包 括矿石采掘装备、矿石破碎装备、矿石收集装备。

矿石采掘装备是海底矿床开采的核心装备之 一, 主要用于将矿床剥离基岩或沉积物, 兼具切割 和掘进的功能。不同矿床种类的采掘装备也不相同: 多金属结核一般赋存于平坦海底，与海底沉积物共 存, 多采用水力式采掘方式, 通过高压水流在结核周 围的负压抽吸作用完成矿石采掘; 富钴结壳生长在 基岩表面，一般采用螺旋滚筒采掘装置将其与基岩 剥离采掘; 多金属硫化物赋存于海底热液区附近, 采掘装备兼具切削和掘进功能, 一般采用辅助切割 机或多功能一体化采掘装备。我国的矿石采掘装备 研制处于原理样机设计和采集试验阶段, 已针对多 金属结核、富钴结壳完成采集试验。2016 年 7 月, 长沙矿山研究院有限公司研制的深海富钴结壳采矿 
表 2 国内深海矿产资源开发装备发展现状

\begin{tabular}{lccc}
\hline 时间/年 & 相关单位 & 水深 $/ \mathrm{m}$ & 试验内容 \\
\hline 2001 & 中国大洋矿产资源研究开发协会 & 135 & 采矿车单体湖试 \\
2016 & 长沙矿冶研究院有限责任公司 & 304 & 输送系统单体海试 \\
2018 & 长沙矿冶研究院有限责任公司 & 514 & 采矿车单体海试 \\
2018 & 长沙矿山研究院有限责任公司 & 2019 & 富钴结壳规模取样车 \\
2019 & 中国科学院深海科学与工程研究所 & 2498 & 采矿车单体海试 \\
\hline
\end{tabular}

头在南海完成了富钴结壳采掘试验, 验证了螺旋滚 筒采矿头采掘富钴结壳矿体的可行性; 2018 年, 长 沙矿山研究院有限公司研制的富钴结壳规模取样器 完成了富钴结壳规模取样器海上试验; 2018 年, 中 国科学院深海科学与工程研究所在我国南海海域完 成了富钴结壳规模采样车试验, 验证了布放回收、 海底矿石破碎等功能。

矿石破碎装备用于大块矿石的海底破碎与分 解。在海底采矿过程中, 往往存在因颗粒过大或需 要与基岩剥离而必须破碎矿石的情况, 因此多用机 械力破碎矿石以便收集。通常, 富钴结壳和硫化物 的开采需采用螺旋滚筒式切削或冲击钻破碎; 多 金属结核开采无需切削设备, 大块矿石可用破碎机 或磨矿机对矿石进行破碎。我国富钴结壳样机配置 了矿石破碎装置并完成海试验证，但针对多金属硫 化物的矿石破碎装备研究较少。2018 年, 在南海 $2500 \mathrm{~m}$ 水深处开展海上试验, 验证了海底矿石破碎 收集能力; 2019 年, 采用深海富钴结壳规模采样装 置, 在南海实施了两次富钴结壳矿石的采集作业, 基于微地形自动适应的切削破碎收集一体化装置, 根据结壳和基岩的物理特性差异来自动判断切削厚 度, 采用水力式收集破碎后的钴结壳碎块并输送到 物料仓。

破碎的小块矿石通过矿石收集装备进入集矿 箱或顺着输送管道转运至海面。我国针对矿石收集 装备的研究开展较早, 针对多金属结核、富钴结 壳的矿石收集装备完成了初步试验验证。19911995 年, 研究了水力式集矿和水力 - 机械复合式 集矿方式。2001 年, 中国大洋矿产资源研究开发 协会联合长沙矿山研究院有限责任公司、长沙矿 冶研究院有限责任公司等单位, 在云南抚仙湖完 成集矿装备 $130 \mathrm{~m}$ 水深湖试, 验证了其可行性。 2018 年, 长沙矿冶研究院有限责任公司研制的 “鲲
龙 500” 采矿车在中国南海完成了 $500 \mathrm{~m}$ 水深海上 试验, 验证了针对多金属结核的海底矿物水力自 适应采集功能 [9]。2018 年, 我国在富钴结壳合同 区完成富钴结壳的综合采集海试; 2019 年, 进一 步开展富钴结壳样机海试, 验证了对富钴结壳碎 块的水力收集能力。

此外, 深海采矿重载作业装备均需配备水下 导航定位系统, 支持完成装备在海底的作业。哈尔 滨工程大学、中国科学院声学研究所、中国船舶集 团有限公司第七一五研究所等多家单位在声学定位 技术领域进行了广泛研究。2004 年, 我国成功研 制出第一套基于差分全球定位系统的水下定位导航 系统; 在国家 “十五” 时期, 成功研制出 “长程 超短基线定位系统”; 在国家 863 计划重点项目的 支持下，成功研制深海高精度水下综合定位系统; 2018 年在 “鲲龙 500 ” 采矿车海试中, 采矿车在 $500 \mathrm{~m}$ 水深处的定位精度达到 $0.72 \mathrm{~m}$ [9]。

\section{（二）矿石输送装备}

矿石输送装备主要用于将海底采集和破碎后的 矿石输送至海面, 包括提升百管装备、水下中继装 备、升沉补偿装置。

提升百管装备用于将矿石 - 海水形成的混合物 以一定的速度和浓度从开采装备输送至海面。深海 采矿应用环境要求提升洜管装备能够克服波浪和海 流等复杂海洋环境的影响, 并具有耐压、耐腐蚀、 耐磨损、允许大粒径颗粒通过、防堵塞、防卡滞 等特点。自 20 世纪 90 年代开始, 大洋协会、长 沙矿治研究院有限责任公司、中南大学、中央民 族大学、上海交通大学等单位针对提升泵管装备、 长距离管道输送等关键技术开展攻关, 取得了系 列成果。自 “八五” 时期开始, 我国建设高度为 $30 \mathrm{~m}$ 的垂直管道提升系统 [10], 研究管道输送特 
性、潜水洜过流回流特性; “十一五” 时期建成高 度为 $224 \mathrm{~m}$ 的垂直管道提升试验系统, 验证了扬 矿工艺的合理性 [6]; 2016 年, 在南海完成 $300 \mathrm{~m}$ 级百管提升系统海上试验, 输送矿浆体积流量为 $500 \mathrm{~m}^{3} / \mathrm{h}$, 结核输送量为 $50 \mathrm{t} / \mathrm{h}$ 。

水下中继装备用于将开采装备采集获得的矿浆 转换为均匀矿并浆输送到提升泵管中, 兼具一定的 辅助控制管道姿态、监测海底作业环境功能。我国 针对深海采矿水下中继装备的研究仍处于设计和试 验阶段, 中南大学设计了将储料罐与水洜组合的水 射流辅助提升矿物中继站 [11]; “十三五” 时期, 中 国船舶集团有限公司第七 $\mathrm{O}$ 二研究所率先研制了用 于海试的水下中继站系统, 进一步提高了我国深海 采矿矿石输送系统的自主设计能力 [12]。

升沉补偿装置是水面支持船与提升泵管装备 之间的重要连接部件, 用于抑制由于水面支持船在 波浪中运动导致的提升原管装备运动。现有的深海 采矿船升沉补偿系统较多借鉴和采用了深海油气钻 探升沉补偿系统方面的技术。振华重工（集团）股 份有限公司、中国石油大学、宝鸡石油机械有限责 任公司、中国船舶集团有限公司第七 $\mathrm{O}$ 四研究所 等对升沉补偿技术进行初步研究并取得一定成果。 2017 年, 宝鸡石油机械有限责任公司研制了我国首 台天车型钻柱升沉补偿装置样机, 性能指标、安全 措施等达到了国外同类产品的技术水平, 增强了我 国深水关键装备的自主配套能力。“十三五” 时期, 中国船舶集团有限公司第七 $\mathrm{O}$ 四研究所进一步开展 升沉补偿装置的研究, 为即将实施的国家重点研发 计划项目海试提供产品配套。

\section{（三）水面支持装备}

深海矿产资源开发装备的水面支持装备包括 水面支持平台、协同控制系统、定位导航系统、 矿石预分选装备、矿石存储外输装备、布放回收 系统。

水面支持平台是深海矿产资源开发活动的水 面中心，包括系统的总体协同控制、动力供给、矿 石预处理、矿石存储和外输, 同时承担水下装备的 布放和回收任务。水面支持平台早期以旧船改造为 主, 将性能相近的货船、钻井船等根据深海采矿活 动需求进行升级改造, 执行海上试验和作业任务。
“十三五” 重点研发计划项目的海试计划, 采用的 水面支持平台即由 “梦娜公主号” 作业船舶改造。 目前, 世界上唯一一艘大型综合采矿船由新加坡 企业为鹦鹉螺矿业公司设计, 在我国福建马尾船 厂建造。虽然我国在大型特种船舶、深海平台的 设计和建造方面具有丰富的经验, 但综合采矿船 需要配备综合电力推进装置, 月池结构, 矿石处 理、储存和外输装置, 系统十分复杂, 国内相关 设计经验较为缺乏。

协同控制系统是指在水面支持船建立中央控制 能力, 既对台设备进行独立的作业控制, 同时实现 多台设备联合作业的智能协同控制, 保证包括布放 回收、采矿作业、矿浆处理外输等环节在内的整个 过程顺利开展。国内在单设备控制方面, 针对采矿 装备作业控制、布放回收过程控制的研究已经逐渐 展开, 对矿浆预分选、外输等过程控制的研究较少; 在深海采矿系统协同控制系统方面的研究尚处于起 步阶段, 未开展海上联调试验, 稳定性和可靠性需 进一步验证。

矿石预分选装备用于将从海里采集到的矿水混 合物进行脱水处理, 保证矿石达到转运的含水量标 准并尽量减少矿物损失。矿石预分选装备还需要将 经过多级处理后的海水经由提升系统业重新打入海 底, 减少对生态环境的破坏。国内深海采矿所使用 的预分选装备的研究工作尚处于起步阶段。采矿船 上的矿石预分选装备主要采用重力式脱水, 五矿集

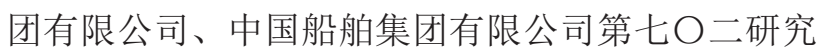
所等单位正在开展有关矿石预分选装备的研究。

矿物存储外输装备用于将脱水处理后的矿物在 采矿船货舱内短暂存储并完成向矿物运输船的转运 工作。国内有关深海采矿用存储外输装备研究工作 尚处于起步阶段, 尚无深海采矿船专用的存储外输 装备，但可借鉴在陆地、自卸式散货船使用的类似 设备。

布放回收装备用于将海底作业装备、中继装 备等布放到海中指定位置, 在作业结束后将其安全 回收到母船上, 承载能力和运行可靠性是关键技 术指标。我国在 2018 年和 2019 年分别完成布放 回收装备的海上试验。中国船舶集团有限公司第 七 $\mathrm{O}$ 四研究所等单位针对重型布放回收装备开展 研制工作。 


\section{四、我国深海矿产资源开发装备发展面临的 问题}

\section{（一）基础科学问题研究尚不充分, 理论支撑较为 薄弱}

一方面, 我国对深海采矿系统动力特性分析能 力不足, 对复杂激励条件下系统的耦合动力响应缺 乏行之有效的分析预报方法; 另一方面, 由于缺少 深水管道输送的工程经验和测试数据, 尚未考虑超 深水作业可能遇到的管道结构力学特性问题, 因而 未能针对深水矿石输运管道开展高性能材料的研发 和生产能力建设。

\section{（二）关键技术未经有效验证，核心装备设计研发 能力较弱}

我国水下海洋环境实时感知技术基础较为薄 弱, 关键技术和装备对国外供应商具有一定的依赖 性，国产自主技术较少; 矿石长距离提升泵技术尚 不完善, 颗粒通过性尚未经历长时间验证, 亟待进 一步发展; 重载装备的布放回收技术、作业过程中 的升沉补偿技术尚待进一步发展, 相应的稳定性和 可靠性需进一步确认。

\section{（三）水下传感器和关键元器件研发能力不足, 对} 外依赖性强

国产组合导航定位装备和算法与国外成熟产品 存在一定的差距, 深水定位精度不够; 国产大功率 深水电缆和光纤技术的稳定性与可靠性有待提高; 深海传感器、水密接插件、中央控制系统等关键元 器件较多依赖进口, 自有产品的稳定性和可靠性仍 需进一步提高。

（四）全系统联合海试尚未开展, 规模化、商业化 开采方案尚未规划

尽管我国已经多次开展单体海试，但是全系统 联合海试涉及内容极为复杂, 依然面临较大挑战。 我国尚未开展深海采矿系统的联合海试, 且无法 完全验证方案设计、关键技术、水下装备。此外, 我国也未开展规模化海试, 对系统生产效率、稳 定性、可靠性、长期运维性能、经济性等尚未开 展深入研究。
（五）环境评估技术有待进一步提高，环境友好型 装备函待研发

发达国家逐步完成了深海采矿的环境影响评 估，建立了分析模型和预报方法。我国尚未对深海 采矿进行完整的环境影响评估, 没有建立完整的环 境影响评估方法。环境友好型的开采和输送装备尚 未形成成熟可用的技术方案。

\section{五、关键科学技术问题与装备重点研发方向}

\section{（一）关键科学技术问题分析}

1. 系统总体设计

系统总体设计即深海矿产资源开发装备系统的 顶层设计, 包括系统设计和研发、总体动力学特性 分析、布放与回收过程动力学响应分析。

系统设计和研发即根据深海矿产资源开发的生 产能力要求, 设计深海矿产资源开发装备, 包括: 水面支持平台、水下输送系统、海底重载作业装备、 整体联动控制系统、电力系统; 在实现基本功能的 基础上，尽可能减小工程作业对海洋生态的影响。

总体系统设计完成后, 应校核系统的动力学性 能, 保证作业过程的安全性, 包括: 总体系统水动 力学特性、水面支持平台与管道连接处结构动力学 特性、升沉补偿系统运动特性、泵 - 管 - 中继站系 统结构应力响应的疲劳特性、采矿车 - 地面相互作 用力学特性等。

采矿车的布放、回收过程一般在温和海洋环境 条件下进行。一方面, 需要根据水面支持平台的能 力、月池尺寸、采矿车尺寸及重量等, 详细设计布 放、回收方案; 另一方面, 需要对布放回收过程中 采矿车的运动、缆绳张力进行动力学分析。此外, 当布放水深为数千米量级时，应考虑由于布放回收 过程中存在的应力波对布放回收系统中缆绳受力突 增的影响 [13]。

\section{2. 海底重载作业装备感知与控制}

海底重载作业装备是深海采矿的直接作业单 元、深海矿石开采的 “最前线”。根据基本功能要 求, 海底重载作业装备应具备环境感知系统、控 制系统、执行系统。环境感知系统是采矿车的 “眼 睛”, 对采矿车周围环境、矿石分布形式进行初步 判断; 控制系统是作业装备的 “大脑”, 控制采矿 
车的行走、转向、爬坡等动作，同时控制矿石的采 集作业; 执行系统用于实施采矿动作, 包括行进装 置和采集装置。

环境感知系统的主要任务是克服海底高噪声、 高扬尘、多颗粒散射的困难, 实现海底工作区域环 境的实时感知和测量, 为采矿车行进、矿石开采提 供基础条件。从感知内容来看, 海底环境感知包 括海底地形、矿石分布; 从测试尺度来看, 环境 感知包括整体环境粗略测量、局部精确测量; 从 实现手段来看, 环境感知可以通过光学、声学成 像技术实现。

控制系统根据感知结果, 实时控制作业装备的 行走和采集，并保持与输送装备、水面支持装备的 实时通信和联合动作。控制系统需要实现海底装备 的实时控制的基本功能, 还需要开展智能化研究, 包括自动路径规划、自动越障避障、智能化控制算 法等。

\section{3. 长距离矿石输送流动保障}

矿石输送装备流动保障针对泵管系统, 研究 矿石颗粒 - 海水形成的大颗粒固液两相流在经过 软管、硬管、提升泵的过程中的流动特性, 并预 报分析可能出现的段塞流、堵塞、磨蚀等问题, 给出合理的优化设计或解决方案。与海洋油气开 采相比, 深海矿石长距离输送管道内存在大尺寸、 较高浓度的固体矿石颗粒, 在输送过程中颗粒对 洜叶轮的冲击和磨蚀明显增加, 泵管系统内发生 堵塞的可能性较大。

流动保障的另一个重要研究方向是系统在紧急 状态下的内部流动控制和解决方案。针对系统停止、 重启等瞬时状态以及部分关键部件（如提升泵、给 料机等)，分析停止工作状态时的泵管系统内固液 两相流的发展状态，提出合理的解决方案。

\section{4. 系统运维与预警}

在深海矿产资源开发作业过程中，需要对各装 备的工作状态开展实时监测。针对矿床开采装备、 泵管提升装备等, 监测其位置、姿态和工作状态; 针对矿浆输送过程, 监测其输送速度及浓度水平; 针对矿石预分选、矿石外输等流程, 监测并调节实 时作业状态，保证采矿作业的正常有序进行。

另一项关键技术是系统的力学响应实时监测 与预警。在作业过程中, 需对深海采矿整体系统
的运动、应力、应变、结构安全进行监测, 结合 深水结构的动力学特征, 对管系的损伤和疲劳状 态进行预警，并针对突发海况、地形变化、生物 干扰等紧急情况作出及时响应预警, 从而以最快 的速度规避风险, 确保整个作业装备的安全。

\section{5. 环境监测与评估}

深海矿产资源开发过程中的环境问题不可忽 略, 包括对海底生态系统的影响、羽状流扩散。针 对海底生态系统, 研制生物生态的长期监测技术装 备, 研究海底生物群落的演变特征, 构建海底生物 数据库。针对海底扰动及尾矿排放形成的羽状流, 研发大尺度、高分辨率的羽状流监测技术装备, 研 究羽状流的扩散和再沉积过程, 建立羽状流实时监 测与跟踪系统。

海底环境影响评估是深海矿产资源开发环境安 全方面的另一个亟待解决的关键问题。分别针对开 采作业可能引起的生态系统影响和羽状流, 通过现 场观测、模型试验、数值模拟等手段, 构建环境影 响评估的技术体系, 为实现绿色环保型的深海矿产 资源开发提供技术支撑。

\section{（二）装备重点研发方向}

1. 深海采矿重载作业装备

针对深海矿床, 采用安全、稳定、高效、绿色 的开发理念, 研发深海采矿重载作业装备。聚焦绿 色开采、稳健行进、智能控制、环境感知, 发展针 对多种矿床的自适应、高效、绿色采集技术; 研发 复杂海底环境下重载作业装备的稳定行进技术。重 点开展重型装备精准控制技术，低照度、高扬尘的 海底环境实时感知技术的研究, 实现海底作业智能 化和无人化。

\section{2. 矿石输送装备}

针对深海矿石超长距离管道输送, 聚焦作业安 全性、输送效率、环境保护，研发大流量、无堵塞、 高效率、轻量化的提升洜管装备, 突破长距离多相 流管道输送流动保障技术、多重复杂激励条件下系 统动力响应预报分析技术。针对商业化开采需求, 研发海上长期运维、监测、调控技术, 适应极端恶 劣海况条件的海上快速解脱和对接技术。

3. 水面支持装备

针对深海矿产资源开发装备体系, 以安全、稳 
定作业为基础, 以无人化、信息化、智能化为目标, 实现系统全生命周期内的协同控制、导航定位、监 测预警、布放回收。重点发展全系统智能化协同控 制技术、超深水高精度组合导航定位及数据融合处 理技术、全系统长期实时监测与即时预警技术、复 杂海况下重载装备布放回收技术、多浮体耦合响应 与精准外输技术。

\section{六、对策建议}

\section{（一）确立深海矿产资源开发发展理念}

我国未来深海矿产资源开发装备的发展将秉持 重装、协同、智能和绿色等理念, 加速推进核心技 术创新和装备自主研发。开发海底大功率、高效能 的重载作业装备, 突破海底多装备联合作业全系统 协同调控技术，基于信息融合、数字孪生体以及 人工智能技术构建海底信息化、无人化、智能化 作业系统, 全面发展绿色开采技术。深海矿产资 源开发基于技术创新、装备研发、海上作业、矿 石处理与综合利用, 构建技术产业链, 实现商业 开采和产业化。

\section{（二）明确关键技术装备研发任务}

根据我国未来深海矿产资源开发装备的发展 理念, 梳理技术装备发展的关键科学问题和 “卡脖 子” 技术, 基于我国的研究基础和研发现状, 明确 亟待解决的重要研究任务。针对深海矿产资源开发 整体系统, 研发全系统协同控制技术、复杂海况下 重载装备布放回收技术、整体动力学特性预报技术; 发展海底采矿重载作业装备环境感知与精准控制技 术; 研制大流量、无堵塞、高效率、轻量化的提升 原管装备, 突破长距离多相流管道输送流动保障技 术、多重复杂激励下动力响应预报分析技术; 针对 系统长期生产作业，研发实时监测及即时预警技术。 应对开采作业的环保要求, 全面构建环境影响评估 技术体系。

\section{（三）实施深海多金属结核开采示范工程}

瞄准我国获得勘探权和优先开采权的深海多金 属结核矿区, 以绿色环保、高效协同为主要目标, 开展海上规模化试采。研究深海矿产资源开发技术
方案, 开展系统总体设计、集成和融合; 研制矿床 开采装备、矿石转运装备、水面控制和辅助开采装 备, 搭载自主核心技术, 建立海底矿床的勘探、开 采、输送、转运技术链; 建立环境监测和评价体系, 实现绿色开采。规模化试采应兼顾富钴结壳、多金 属硫化物开采, 为相关技术验证提供海上试验基地 和平台。

规模化试采后，着手商业化开采。注重深海采 矿的经济性和环保性，建立分析评估体系。从短期 试验发展到商业化开采, 必须进一步考虑系统在海 上长期作业的运行和维护，形成完整的长期运维、 监测、调控系统。兼顾极端情况下的系统应急需求, 发展水面 - 水下快速解脱和回接技术。

\section{参考文献}

[1] 阳宁, 陈光国. 深海矿产资源开采技术的现状综述 [J]. 矿山机 械, 2010, 38(10): 4-9.

Yang N, Chen G G. Status quo and development trendency of deep sea minerals mining technology [J]. Mining \& Processing Equipment, 2010, 38 (10): 4-9.

[2] Mero J L. The mineral resources of the sea [M]. Amsterdam: Elsevier Oceanography Series, 1965.

[3] Van Wijk J M. Vertical hydraulic transport for deep sea mining: A study into flow assurance [D]. Netherlands: Delft University of Technology(Doctoral dissertation), 2016.

[4] Chung J S. Deep-ocean mining technology: Development II [C]. Changsha: Proc 6th ISOPE Ocean Mining Symposium, 2005: 1-6.

[5] 刘否. 深海采矿水力提升固液两相流动力学特性研究 [D]: 上海 交通大学(博士学位论文), 2019.

Liu L. Research on dynamic performance of solid-liquid twophase flow in hydraulic transport in deep sea mining [D]. Shanghai: Shanghai Jiao Tong University(Doctoral dissertation), 2019.

[6] 唐达生, 阳宁, 金星. 深海粗颗粒矿石垂直管道水力提升技术 [J]. 矿冶工程, 2013, 33(5): 1-8.

Tang D S, Yang N, Jin X. Hydraulic lifting technique with vertical pipe for deep-sea coarse mineral particles [J]. Mining and Metallurgical Engineering, 2013, 33(5): 1-8.

[7] 肖业祥, 杨凌波, 曹蕾, 等. 海洋矿产资源分布及深海扬矿研究 进展 [J]. 排灌机械工程学报, 2014, 32(4): 319-26.

Xiao Y X, Yang L B, Cao L, et al. Distribution of marine mineral resource and advances of deep-sea lifting pump technology [J]. Journal of Drainage and Irrigation Machinery Engineering, 2014, 32(4): 319-26.

[8] 李江海, 宋玨琛, 洛怡. 深海多金属硫化物采矿研究进展及其前 景探讨 [J]. 海洋开发与管理, 2019, 36(11): 29-37.

Li J H, Song J C, Luo Y. Research progress and prospect of deep sea polymetallic sulfide mining [J]. Ocean Development and Management, 2019, 36(11): 29-37.

[9] 彭建平. 中国深海多金属结核采矿车研究的发展 [J]. 矿山机械, 2020, 48(3): 8-11. 
Peng J P. Development of research on deep-sea polymetallic nodule mining vehicle in China $[\mathrm{J}]$. Mining \& Processing Equipment, 2020, 48(3): 8-11.

[10] 刘少军, 刘畅, 戴瑜. 深海采矿装备研发的现状与进展 [J]. 机械 工程学报, 2014, 50 (2): 8-18.

Liu S J, Liu C, Dai Y. Status and progress on researches and developments of deep ocean mining equipments [J]. Journal of Mechanical Engineering, 2014, 50(2): 8-18.

[11] 徐海良, 周刚, 吴万荣, 等. 深海采矿储料罐输送设备固液两 相流数值计算与分析 [J]. 中南大学学报(自然科学版), 2012, 43(1): 111-117.

Xu H L, Zhou G, Wu W R, et al. Numerical calculation and analysis of solid-liquid two-phase flow in tank transporting equipment for deep-sea mining [J]. Journal of Central South University(Science and Technology), 2012, 43(1): 111-117.

[12] 曹阳, 杜新光, 宋环峰, 等. 深海采矿水下中继站结构强度分析 和校核 [J]. 船海工程, 2020, 49(3): 136-9.

Cao Y, Du X G, Song H F, et al. Overall strength analysis and assessment of underwater buffer station in deep sea mining [J]. Ship \& Ocean Engineering, 2020, 49(3): 136-9.

[13] 吴丞昊. 深海采矿长缆线布放系统内应力波的产生及传播特性 研究 [D]. 上海: 上海交通大学(硕士学位论文), 2017.

$\mathrm{Wu} \mathrm{C} \mathrm{H}$. Study on the causes and propagating characteristics of stress waves in a deep-sea mining deployment cable [D]. Shanghai: Shanghai Jiao Tong University(Master`s thesis), 2017. 